\title{
A New Variant of Sandhoff's Disease
}

\author{
Matthew W. Spence, ${ }^{[54]}$ Beverly A. Ripley, Juan A. Embil, \\ and John A. R. Tibbles \\ Departments of Pediatrics, Biochemistry, and Microbiology, Dalhousie University, and The Izaak Walton \\ Killam Hospital for Children, Halifax, Nova Scotia, Canada
}

\begin{abstract}
Extract
A 28-month-old Negro male with atypical Sandhoff's disease $\left(\mathrm{GM}_{2}\right.$ gangliosidosis, type 2) is described. Clinical presentation closely resembled Sandhoff's disease. The appendiceal neuron cytoplasm was distended with periodic acid-Schiff (PAS)-positive material. Hepatic glycolipid $N$-acetylneuraminic acid was elevated 1.5 -fold, chiefly because of increased $\mathrm{GM}_{2}$. Neutral glycolipid hexose was elevated twofold, mainly because of a component with globoside-like chromatographic properties. Unlike patients with Sandhoff's disease, the child had total $\beta$-D- $N$-acetylhexosaminidase activity $20-24 \%$ of normal in serum and plasma and $7-11 \%$ of normal in leukocytes and cultured fibroblasts, but activity in liver $(<2 \%$ of normal) was similar to that in Sandhoff's disease. In all tissues examined, $>95 \%$ of the activity was heat denaturable, corresponding in electrophoretic mobility to the heat-denaturable component of normal tissues. The decrease in heat-denaturable activity with time and the $\mathrm{pH}$ optimum were similar in patient and control crude tissue preparations and partially purified preparations of plasma hexosaminidase A. In the child's mother, total hexosaminidase activity was approximately $50 \%$ of mean control values in serum, plasma, and leukocytes, and serum hexosaminidase A was relatively increased. This finding, together with the death of at least three other children in the kindred from an apparently phenotypically similar illness, indicates the inherited nature of the disorder.
\end{abstract}

\section{Speculation}

Appreciable hexosaminidase activity in serum and plasma and its marked deficiency in liver suggest that the active form (or forms) in serum and plasma differ from those in solid tissues, and that the mutation in the case described has altered the hexosaminidases in a manner that virtually abolishes their activity in solid tissues but permits their partial activity in serum and plasma.

\section{Introduction}

Three genetic diseases are characterized by the accumulation of ganglioside $\mathrm{GM}_{2}$ : Tay-Sachs disease $\left(\mathrm{GM}_{2}\right.$ gangliosidosis, type 1), Sandhoff's disease (type 2), and juvenile $\mathrm{GM}_{2}$ gangliosidosis (type 3) [20,47]. All are evidenced by a defect in one or both of the $\mathrm{A}$ and $\mathrm{B}$ forms of $\beta$-D- $N$-acetylhexosaminidase activity; hexosa- minidase $\mathbf{A}$ is nearly absent in Tay-Sachs disease [22] and is reduced in the juvenile form [33]. Although Sandhoff's disease is referred to as the "absent hexosaminidase" variant, some activity ( $<10 \%$ of normal) has been detected in all tissues examined, predominantly as a component similar to hexosaminidase A [12, 21, 29, 31, 39]. In both Tay-Sachs and Sandhoff's 
diseases, the brain contains 100-300 times normal amounts of ganglioside $\mathrm{GM}_{2}$; in Sandhoff's disease the visceral organs, also, contain abnormal amounts of asialo $\mathrm{GM}_{2}$ and globoside [21, 29, 39].

Recently we studied a case of what appears to be a variant of Sandhoff's disease, in that the hexosaminidase A levels in serum and plasma, and to a lesser extent in leukocytes and cultured fibroblasts, are higher than in other reported cases.

\section{Case Report}

The patient, a Negro male, was 28 months old when referred for consultation. Development was considered to have been normal in the 1st year, but then his achievements plateaued. From age 20 months he appeared to regress slowly, stumbling easily, feeding poorly, drooling, and becoming less able to communicate. Brief akinetic seizures, noted at 23 months, were unrelated to fever and were controlled by phenobarbi$\mathrm{tal}, 60 \mathrm{mg} / 24 \mathrm{hr}$ in divided doses.

The boy was handsome, but he drooled and his behavior was that of a 9-12-month-old. Height was 91 $\mathrm{cm}$, weight $13.5 \mathrm{~kg}$, and head circumference $52 \mathrm{~cm}$. The retinal maculae contained areas of degeneration surrounded by pale haloes, and the optic discs were pale. Deep tendon reflexes and plantar responses were normal, and no excessive startle response was observed. The muscle was of decreased bulk and moderately hypotonic, the joints were lax, and there were small bilateral inguinal herniae and an umbilical hernia. His liver and spleen were not enlarged.

The hemogram was consistently normal, and no vacuolated leukocytes were demonstrable on smears. Serum electrolyte, creatine phosphokinase, and serum glutamic pyruvic transaminase values were normal, but serum glutamic oxaloacetic transaminase was 152 $\mathrm{U}$ (normal, 0-45) and lactic dehydrogenase (LDH) was 1, I64 U (normal, 250-500)/100 ml, with slight increases in $\mathrm{LDH}$ isoenzymes 1 and 2. Amino acid chromatography of the urine showed slightly increased carnosine and phosphoethanolamine, and examination for acid mucopolysaccharides [7] revealed increased uronic acid in the material precipitable by cetylpyridinium chloride (patient, $6.6 \mathrm{mg} / 24 \mathrm{hr}$; control subjects, mean $2.9 \pm$ 0.03 SEM). Thin layer chromatography (TLC) of the cetylpyridinium chloride-precipitable material showed a minor component with chromatographic mobility similar to that of chondroitin sulfate, and a major component, staining purple with ortho-toluidine blue, with mobility slower than that of chondroitin sulfate or heparin.
Roentgenographic skeletal survey was normal. The EEG showed generalized paroxysmal activity during sleep, with well preserved background rhythms.

Samples of liver, muscle, and appendix were obtained at laparotomy, and of skin and sural nerve at biopsy. Both frozen and fixed specimens of liver, muscle, and sural nerve were histologically normal; in particular, the liver contained no storage cells and the Kupffer cells appeared normal. In the appendix, the cytoplasm of ganglion cells in both the Meissner and the Auerbach plexuses was greatly distended and it stained intensely with PAS in cryostat-cut sections.

The child's father was recently (accidentally) deceased. His mother, who was in good health, had been adopted; her adoptive parents stated that she was indirectly related to her husband but that they did not know the exact relation. In 1966, one of us $(J T)$ diagnosed amaurotic familial idiocy in a female paternal cousin, then aged 16 months, who had evidenced developmental deterioration from the age of 9 months. When seen by $J T$ she had optic atrophy and rusty brown pigmentation of the retinal maculae; ganglion cells and neurons of rectal and brain biopsy contained accumulated material with the staining characteristics of a ganglioside. Two of this cousin's eight siblings, and another child in the same deme, had had a similar clinical picture; their condition had deteriorated progressively and all had died between 3 and 4 years of age.

\section{Materials and Methods}

Serum was obtained once and plasma and leukocytes three times over the 4-month period of study. One sample of plasma and one of leukocytes were obtained and liver biopsy was performed when the patient had had no anticonvulsant therapy for 1 week. The mother gave informed consent for all of the investigations.

Serum was obtained from freshly collected blood clotted at $4^{\circ}$ for $30 \mathrm{~min}$, and plasma from the supernatant fraction of the leukocyte isolation. Preliminary studies indicated no difference in hexosaminidase activity in plasma thus obtained and in heparinized blood. Leukocytes were isolated by sedimentation in dextran [1], subjected to osmotic shock [38], frozen and thawed seven times, and sedimented at 3,000 $\times g$ for $10 \mathrm{~min}$; the supernatant fraction was used. Tissues were frozen immediately and were held at $-20^{\circ}$ until analyzed.

The primary cell culture of fibroblast-like cells (called fibroblasts) was obtained from fragments of leg 
skin (explants) and cultured in Eagle's minimal essential diploid medium containing $10 \%$ fetal calf serum [4]; monolayers were maintained by adding $5 \%$ fetal calf serum and $5 \%$ calf serum. When the monolayers were confluent, the cells were harvested by trypsinization and were washed three times with Eagle's minimal essential diploid medium. Control fibroblast cells were obtained similarly from cultures of neonatal human foreskins. Cell homogenates were prepared for measurement of hexosaminidase activity (details under Results).

Total lipids were extracted from liver tissue by repeated homogenization in chloroform-methanol $(2 / 1$, $2 / 1,1 / 2 ; \mathrm{v} / \mathrm{v})$; the pooled extracts were evaporated to dryness under $\mathrm{N}_{2}$, taken up in chloroform-methanol, $2 / 1$, and washed [5]. For the upper phase, total glycolipid $N$-acetylneuraminic acid $[17,40]$ and individual ganglioside proportions [16] were determined, using mixed bovine brain ganglioside and $\mathrm{GM}_{1}$ and $\mathrm{GM}_{2}$ gangliosides [49] as standards. For the lower phase, cholesterol [2], glycolipid hexose [9], and phospholipid patterns [24, 28] were determined; neutral glycolipids were isolated by silicic acid chromatography and were separated into individual components by TLC [41].

Table I. Some major constituents of liver biopsy from the patient and from necropsy control samples

\begin{tabular}{|c|c|c|c|}
\hline Liver & Patient & (meal & $\begin{array}{l}\text { Controls }{ }^{1} \\
\text { n and range) }\end{array}$ \\
\hline $\begin{array}{l}\text { Dry weight (mg/g fresh tis- } \\
\text { sue) }\end{array}$ & 36.20 & 28.70 & $(26.2-31.0)$ \\
\hline $\begin{array}{l}\text { Constituents (mg/100 mg dry } \\
\text { wt) }\end{array}$ & & & \\
\hline Lipid & 11.70 & 11.70 & $(10.51-14.21)$ \\
\hline Total cholesterol & 1.05 & 1.19 & $(0.97-1.32)$ \\
\hline Free cholesterol & 1.00 & 0.98 & $(0.76-1.20)$ \\
\hline Neutral glycolipic & 0.35 & 0.18 & $(0.11-0.26)$ \\
\hline Phospholifid phosphorus & 0.31 & 0.26 & $(0.21-0.28)$ \\
\hline
\end{tabular}

1 Two or three necropsy specimens of liver from each of four males, aged 1,7, 9, and 16 years. These specimens were used as controls for phospholipid measurements also.

\begin{tabular}{ccc} 
Table II. Liver gangliosides & & \\
\hline Ganglioside & Patient & Controls \\
\hline $\mathrm{GM}_{3}$ & 5.6 & 7.6 \\
$\mathrm{GM}_{2}$ & 5.8 & 0.5 \\
$\mathrm{GM}_{1}$ & 1.8 & 0.6 \\
Slower $^{3}$ & 1.8 & 1.2 \\
\hline
\end{tabular}

1 Glycolipid $N$-acetylneuraminic acid $(\mu \mathrm{g} / 100 \mathrm{mg}$ dry wt).

2 Caucasian males, aged $l$ and 7 years; mean value.

${ }^{3}$ Gangliosides migrating slower than $\mathrm{GM}_{1}$ on thin layer chromatography.
Reference glycolipids were obtained by acid hydrolysis of mixed brain gangliosides [13], and characterized by TLC followed by gas-liquid chromatography [41].

$\beta$-D- $N$-Acetylhexosaminidase A was partially purified [44] from the patient's and normal plasma, by salt fractionation and DEAE-Sephadex chromatography [50]. $\beta$-D- $N$-Acetylhexosaminidase activity was measured [22] with 4-methylumbelliferyl (4-MU) derivatives of $\beta$-D- $N$-acetylglucosaminide (GlcNAc) or $\beta$-D- $N$-acetylgalactosaminide (GalNAc) [51], and protein was determined by the method of Lowry et al. [15]. Cellulose acetate electrophoresis [52] was performed at $0-4^{\circ}$ in 0.02 m citrate phosphate buffer, $\mathrm{pH} 6.0$ or 7.0 , for 1.5 hr at 2.5-3.0 ma/strip. Enzyme activity was located by incubating the strips with $1 \mathrm{~mm} 4-\mathrm{MU}-\mathrm{GlcNAc}$ in citrate phosphate buffer $(0.04 \mathrm{M}, \mathrm{pH} 4.4)$ at $37^{\circ}$ for 30 $\min [14]$.

\section{Results}

\section{Hepatic Lipid Analysis}

Only $500 \mathrm{mg}$ frozen tissue was available for chemical analysis. Compared with control samples stored for longer periods under identical conditions, the dry weight of the patient's liver tissue was increased (Table 1 ); less than a quarter of the increase could be accounted for by chloroform-methanol-soluble lipid material. Neutral glycolipid hexose was increased, total phospholipids were slightly elevated, and cholesterol and cholesterol esters were within normal range. Apart from lysolecithin, which was elevated almost twofold, individual phospholipids were only slightly $(<5 \%)$ affected: sphingomyelin and lecithin were slightly increased, and phosphatidyl serine and ethanolamine slightly decreased. Glycolipid $N$-acetylneuraminic acid was increased 1.5-fold (Table II), mainly because of increased amounts of a ganglioside with chromatographic properties similar to those of $\mathrm{GM}_{2}$. $\mathrm{GM}_{1}$, and, to a lesser extent, the minor polysialogangliosides, were increased; but $\mathrm{GM}_{3}$, normally the major hepatic ganglioside, was decreased. TLG of the neutral glycolipid fraction after silicic acid chromatography showed a major increase in a component with mobility similar to that of globoside ( $N$-acetylgalactosaminylgalactosylgalactosylglucosyl ceramide), and an apparently incompletely separated material, above the globoside spot, that might represent asialo $\mathrm{GM}_{2}$ (Fig. 1). (The ceramide tetrahexoside formed by acid hydrolysis of gangliosides, which is a different species from globoside. had a lower chromatographic mobility; see also 


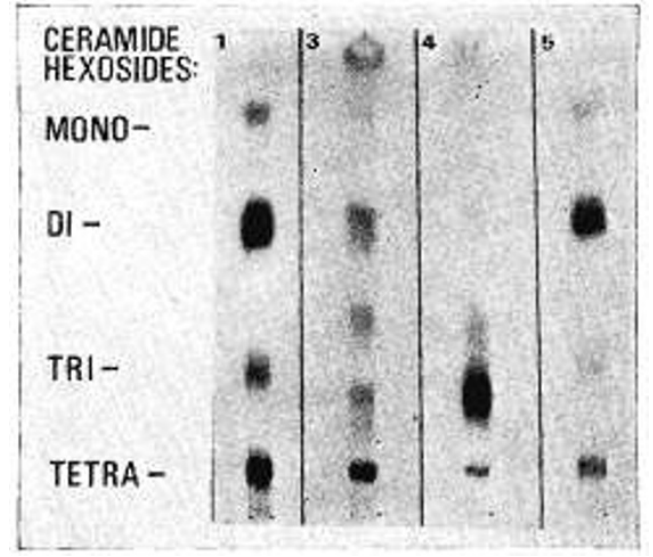

Fig. 1. Thin layer chromatogram of liver neutral glycolipids. Glycolipids were partially purified by silicic acid column chromatography [41]. Lanes I and 5: neutral glycolipid standards prepared by mild acid hydrolysis of mixed bovine brain gangliosides; lane 2: (blank), deleted; lane 3: control, aged 7 years; lane 4: patient. Solvent system, chloroform-methanol- $\mathrm{H}_{2} \mathrm{O}(70 / 30 / 4, \mathrm{v} / \mathrm{v} / \mathrm{v})$. Glycolipids were visualized by spraying with aniline diphenylamine [35].

Reference 39.) Unfortunately, the small amounts of material available precluded further glycolipid characterization.

\section{Enzyme Assay}

Two of the control subjects from whom plasma was obtained were Negro children (one male, one female) aged 1 year. The patient's total serum hexosaminidase activity was $24 \%$ of mean control levels; $>95 \%$ of this was the A fraction as determined by heat denaturation (Table III). (The serum hexosaminidase activity of a patient with Tay-Sachs disease was unaffected by heat denaturation in these experiments.) Further, on cellu-

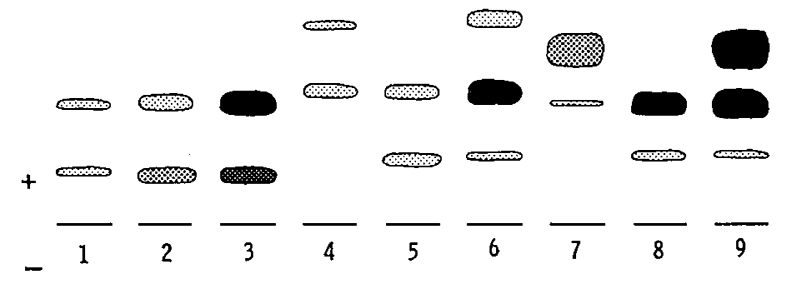

Fig. 2. Cellulose acetate electrophoresis (conditions described in text). Composite tracing of $\beta$ - $\mathrm{D}-\mathrm{N}$-acetylhexosaminidase activity from serum, leukocytes, and fibroblasts. Lane 1: patient's fibroblasts; lane 2: control fibroblasts, heat denatured; lane 3: control fibroblasts; lane 4: patient's leukocytes; lane 5: control leukocytes, heat denatured; lane 6: control leukocytes; lane 7: patient's serum; lane 8: control serum, heat denatured; lane 9: control serum.

lose acetate electrophoresis, the major band of activity migrated the same as the heat-denaturable band in normal serum; only a faint trace of activity was observed in the heat-stable (hexosaminidase B) area (Fig. 2). Plasma activity was $20 \%$ of control level, predominantly $(>95 \%)$ hexosaminidase A (Table III), and its electrophoretic mobility (not shown) was similar to that of serum. Leukocyte hexosaminidase activity in frozen/thawed leukocytes, which averaged $10 \%$ of mean control values, was $>95 \%$ heat denaturable. On electrophoresis it corresponded to the two fast control bands; the fastest migrating and a portion of the second control band disappeared during heat denaturation (Fig. 2). Plasma and leukocyte activities were unchanged in the sample taken at the end of the no medication period. The patient's nonfrozen homogenized leukocytes, with and without bovine serum albumin (BSA), had total activity $12-15 \%$ of control values; however, in both patient and control samples, freezing/thawing increased leukocyte activity by $25-$

Table III. $\beta$-D-N-Acetylglucosaminidase activity of serum, plasma, leukocytes, and liver ${ }^{1}$

\begin{tabular}{|c|c|c|c|c|c|c|}
\hline \multirow[t]{2}{*}{ Enzyme source } & \multicolumn{3}{|c|}{ Patient ${ }^{2}$} & \multicolumn{3}{|c|}{ Mean control } \\
\hline & $n$ & Total activity & Hexosaminidase A, \% & $n$ & Total activity & Hexosaminidase A, \% \\
\hline Serum & 1 & 258 & 97.5 & 6 & $\begin{array}{c}1,095 \\
(943-1,275)\end{array}$ & $\begin{array}{c}66.8 \\
(63.4-70.0)\end{array}$ \\
\hline Plasma & 3 & $\begin{array}{c}187 \\
(162-212)\end{array}$ & $\begin{array}{c}96.1 \\
(95.7-96.8)\end{array}$ & 5 & $\begin{array}{c}895 \\
(666-1,230)\end{array}$ & $\begin{array}{c}58.5 \\
(52.5-70.7)\end{array}$ \\
\hline Leukocytes & 3 & $\begin{array}{c}493 \\
(287-650)\end{array}$ & $\begin{array}{c}96.4 \\
(95.8-97.4)\end{array}$ & 6 & $\begin{array}{c}4,717 \\
(2,325-5,846)\end{array}$ & $\begin{array}{c}87.4 \\
(82.0-90.1)\end{array}$ \\
\hline Liver & 1 & 17 & 83.5 & 3 & $\begin{array}{c}1,192 \\
(951-1,571)\end{array}$ & $\begin{array}{c}54.9 \\
(49.2-60.8)\end{array}$ \\
\hline
\end{tabular}

1 Mean and range. Total activity: serum and plasma, nmol/ml/hr; leukocytes and liver, nmol/mg $\mathrm{protein} / \mathrm{hr}$. Hexosaminidase $\mathrm{A}$ (percentage of total activity) was determined by subtracting the heat-stable $\left(50^{\circ}\right.$ ) activity from the total.

2 Plasma and leukocyte samples were obtained over a 4-month period. 
Table IV. $N$-Acetyl- $\beta$-D-glucosaminidase activity of cultured fibroblasts ${ }^{1}$

\begin{tabular}{|c|c|c|c|c|c|c|}
\hline \multirow[t]{2}{*}{ Homogenate treatment ${ }^{2}$} & \multicolumn{3}{|c|}{ Patient } & \multicolumn{3}{|c|}{ Control } \\
\hline & $n$ & Total activity & Hexosaminidase A, \% & $n$ & Total activity & Hexosaminidase A, \% \\
\hline Homogenized; frozen and thawed & 5 & $\begin{array}{c}0.33 \\
(0.2-0.47)\end{array}$ & $\begin{array}{c}95.7 \\
(94.9-96.4)\end{array}$ & 5 & $\begin{array}{c}4.12 \\
(2.00-5.12)\end{array}$ & $\begin{array}{c}54.5 \\
(5 \mathrm{I} .3-56.3)\end{array}$ \\
\hline BSA; homogenized; frozen and thawed & 1 & 0.32 & 94.8 & 1 & 2.75 & 47.5 \\
\hline BSA; homogenized; not frozen & 5 & $\begin{array}{c}0.49 \\
(0.4-0.66)\end{array}$ & $\begin{array}{c}96.0 \\
(92.4-98.3)\end{array}$ & 5 & $\begin{array}{c}4.46 \\
(3.10-6.70)\end{array}$ & $\begin{array}{c}52.2 \\
(48.5-57.5)\end{array}$ \\
\hline
\end{tabular}

${ }_{1}$ Mean and range of activity are shown. Total activity, $\mu \mathrm{mol} / \mathrm{mg}$ protein $/ \mathrm{hr}$; hexosaminidase A, percentage of total activity. Hexosaminidase was assayed with $0.1 \%$ bovine serum albumin present. The A contribution to total activity was determined by heating the homogenate at $50^{\circ}$ for $3 \mathrm{hr}$. Cultured fibroblasts were obtained from leg skin from the patient and foreskin from two neonates. Five paired (patient and control subjects) cultures (3rd to 9th passage) were analyzed after 7-28 days in subculture.

${ }^{2}$ BSA : bovine serum albumin, $0.1 \%(\mathrm{w} / \mathrm{v})$. Cell samples were homogenized in a glass mortar with a Teflon pestle. The buffer contained $0.15 \mathrm{M} \mathrm{NaCl}$ and $0.01 \mathrm{~m}$ potassium phosphate, $\mathrm{pH} 7.4$, with or without BSA. Where indicated, the homogenate was frozen $\left(-70^{\circ}\right)$ and thawed $\left(0-4^{\circ}\right)$ seven times before analysis.

$50 \%$. Freezing/thawing had little effect on plasma activity. The $\mathrm{pH}$ versus activity curves for patient and control samples of serum and leukocytes were similar; $\mathrm{pH}$ optimum was 4.3-4.5. Hepatic hexosaminidase activity was $<2 \%$ of mean control value, and was $83.5 \%$ heat denaturable. The patient's mother had hexosaminidase activity $42.5 \%(467 \mathrm{nmol} / \mathrm{ml} / \mathrm{hr})$ of mean control activity, with $81 \% \mathrm{~A}$, in serum; $53.7 \%(480$ $\mathrm{nmol} / \mathrm{ml} / \mathrm{hr}$ ), with $72.2 \% \mathrm{~A}$, in plasma taken 4 months later; and $50.5 \%$, with $88 \%$ hexosaminidase A, in leukocytes.

Hexosaminidase activity of cultured cells was determined between the 3rd and 9th subculture. For both normal and patient fibroblast preparations, with $0.1 \%$ BSA in the incubation medium the reaction rates were linear to $30 \mathrm{~min}$ and without BSA the rates were nonlinear with time. The $\mathrm{pH}$ optimum was 4.4 for patient and control fibroblasts. The homogenates of cells from the patient, after freezing/thawing, had $7.4 \%$ of mean control activity; $95.7 \%$ was heat denaturable, compared with $54.5 \%$ in control samples (Table IV). The addition of BSA to the homogenate and omission of freezing/thawing increased mean total activity to $11 \%$ of mean control value (which also rose), but little affected the proportion of hexosaminidase A. Further reduction in the time spent in preparation of cells for assay did not enhance activity. On electrophoresis, control and patient cells showed two bands of activity (Fig. 2); heat denaturation reduced the staining intensity of both control bands, particularly the faster one.

The fetal calf serum used to support cell growth is rich in hexosaminidase. However, contamination from this source was unlikely with our experimental condi- tions, in which the A activity of the medium was only $22 \%$. Thus, any such contamination should have enriched the $B$ fraction in fibroblasts from the patient, but this was not observed.

The $\alpha$ - and $\beta$-galactosidase activities in cultured $\mathrm{fi}$ broblasts and preparations of isolated leukocytes from the patient were within normal range. The possibility of inhibitors of enzyme activity in patient tissues, or activators in control tissues, was excluded by experiments in which fibroblasts from both sources were mixed in various proportions; substrate hydrolysis rates were as predicted from the measurement of activity in individual fractions.

Although the heat-stable enzyme activity in fibroblasts from the patient was only $5 \%$ of total (Table IV), compared with $48-57 \%$ in control samples, the pattern of activity loss with duration of heating in both was similar (Fig. 3). The patient's cell activity tended to disappear slightly faster when heated, but this difference was significant only at $30 \mathrm{~min}(P<$ $0.02)$.

Hexosaminidase A was partially purified from the patient's plasma, from a control sample (sample I in Table V) stored at $-20^{\circ}$ for a similar time, and from a fresh unfrozen sample (sample $I I$ ). The A activity per milligram of protein (based on the amount of heat-denaturable activity in the starting material) was enriched 13-fold in plasma from the patient and 39. and 45 -fold in the control samples (recovery of hexosaminidase A was 9.0, 17.6, and 19.2\%, respectively). Cellulose acetate electrophoresis of the partially purified material from patient and control subjects showed a single band of hexosaminidase activity which corre- 


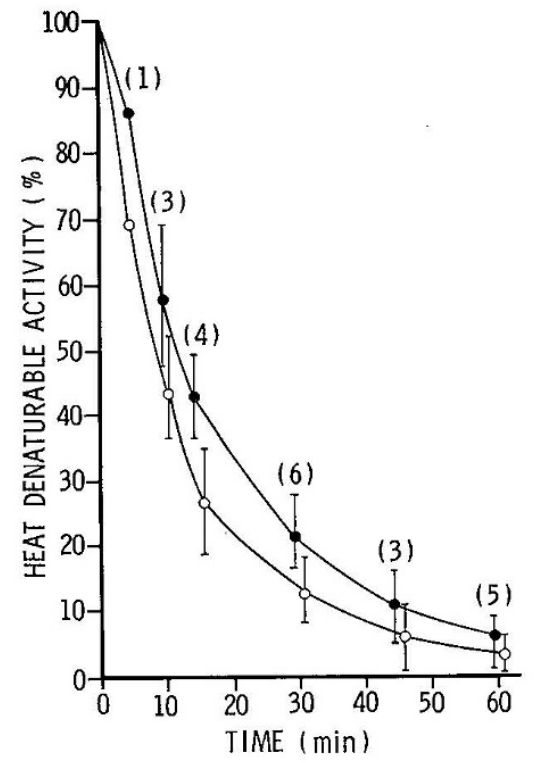

Fig. 3. Heat denaturation of fibroblast $\beta$-D- $N$-acetylglucosaminidase. Three individual lots of fibroblasts served as enzyme source for patient and control samples. Fibroblast homogenates were diluted $(\mathrm{l} / 40-1 / 8)$ with citrate $\mathrm{PO}_{4}$ buffer, $0.04 \mathrm{M}, \mathrm{pH} 4.4$, and bovine serum albumin was added to a final concentration of $0.1 \%$. The samples were heated at $50^{\circ}$ for appropriate times. (The heat-denaturable activity only is plotted, for direct comparison of patient $(95.7 \%$ of total) and control $(54.5 \%$ of total) sample heat-labile activity.) $\bigcirc$ : patient sample; $\bullet$ : control sample; mean values $\pm \mathrm{sD}$, with number of heat-denaturation experiments in parentheses.

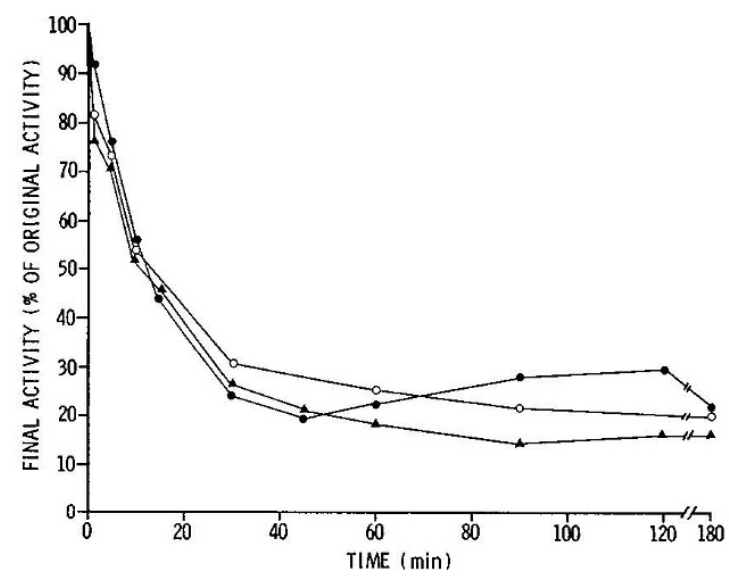

Fig. 4. Heat denaturation of partially purified plasma hexosaminidase A. Partially purified plasma enzyme $(0.2 \mathrm{ml})$ was diluted to $1 \mathrm{ml}$ with citrate phosphate buffer, $0.04 \mathrm{M}, \mathrm{pH} 4.4$, and $1 \mathrm{mg}$ bovine serum albumin was added. The samples were heated at $50^{\circ}$ for appropriate times. $\bigcirc$ : patient sample; $\mathbf{\Delta}$ : control sample I; $\bullet$ : control sample II. Values are average of two separate experiments.
Table $V . \mathrm{K}_{\mathrm{m}}$ and $\mathrm{V}$ values for partially purified plasma hexosaminidase A samples from patient and control subjects ${ }^{1}$

\begin{tabular}{lccc}
\hline & Patient & $\begin{array}{c}\text { Conirol } \\
\text { sample I }\end{array}$ & $\begin{array}{c}\text { Control } \\
\text { sample II }\end{array}$ \\
\hline $\mathrm{K}_{\mathrm{m}}$ (mol/liter $\left.\times 10^{-4}\right)$ & & & \\
4-MU-GlcNAc & 8.7 & 7.5 & 7.5 \\
4-MU-GalNAc & 1.80 & 0.95 & 0.95 \\
V (nmol/hr/mg protein) & & & \\
4-MU-GlcNAc & 13.7 & 71.4 & 91.8 \\
4-MU-GalNAc & 0.5 & 4.0 & 6.5 \\
\hline
\end{tabular}

${ }_{1}^{1}$ Control samples were obtained from healthy male donors Control sample $I$ and the patient sample were stored at $-20^{\circ}$ for a similar period; control sample II was processed unfrozen. 4MU-GINAc: 4-methylumbelliferyl- $\beta$-D- $N$-acetylglucosaminide; 4-MU-GalNAc: 4-methylumbelliferyl $-\beta-\mathrm{D}-N$-acetylgalactosaminide.

sponded to the most rapidly migrating heat-denaturable serum band (A fraction), and their heat denaturation patterns with $0.1 \%$ BSA were similar (Fig. 4). An unexpected finding was the relatively large amount of heat-stable material $(15.5-22 \%)$ in both patient and control samples, particularly as the heat-stable activity in the plasma of the patient was very low $(<5 \%$; Table III) before purification. Total activity of the partially purified plasma enzyme from patient and control subjects was linear with time to $1 \mathrm{hr}$ with both 4-MU-GlcNAc and GalNAc as substrates; the $\mathrm{pH}$ optimum with GlcNAc was 4.0-4.6, and the curve was broad and flat for patient and control preparations. Variation in substrate concentration revealed a much lower $\mathrm{K}_{\mathrm{m}}$ and maximal velocity for GalNAc in normal and patient partially purified plasma; with both substrates, the patient's enzyme $\mathrm{K}_{\mathrm{m}}$ value was slightly higher (Table V) and maximal velocity was much lower than that for control subjects.

\section{Discussion}

Apart from the absence of excessive startle response to sound, the clinical presentation in this case resembles that described for Sandhoff's disease [21, 29, 30]. Histologically, abnormalities in the tissues available for study were confined to the appendiceal neurones, which were greatly enlarged and contained PAS-staining material in the cytoplasm. Chemical analysis of solid organ tissue was limited to the small sample of liver, precluding extensive study. Less than $25 \%$ of the increased dry weight of this sample could be accounted for by increased chloroform-methanol-extractable material; the other $>75 \%$ may have been stored polysaccharide, as in liver in $\mathrm{GM}_{1}$ gangliosidosis type $I$ [48], 
and in brain in one reported case of type II [39], particularly in view of our patient's increased urinary excretion of some polysaccharide component. However, this increase in dry weight must be interpreted cautiously; despite precautions, the sample may have become desiccated during storage. The notable findings in the hepatic lipid analysis were increased amounts of a $\mathrm{GM}_{2}$-like ganglioside and of a neutral glycolipid tentatively identified as globoside (Table II and Fig. 1). Globoside accumulation in visceral tissues chemically distinguishes Sandhoff's from Tay-Sachs disease [29]; visceral storage of $\mathrm{GM}_{2}$ occurs in both conditions, the absolute amounts varying from case to case [12, 21, 29].

Thus, the clinical, histologic, and chemical features in this case resemble closely those in cases of Sandhoff's disease [21, 29, 39]. Enzyme studies, however, revealed important differences. Using mostly artificial substrates, hexosaminidase activity has been reported to the $<5 \%$ of control in serum and plasma $[3,10,12,21$, 45 , and, in two cases, $5 \%$ and $7.9 \%$ of control in whole blood [8]. This activity was reported as predominantly hexosaminidase $\mathrm{A}$, on the basis of heat denaturation and/or electrophoretic separation, but as much as $40 \% \mathrm{~B}$ has been observed [12]. Our patient had $20-24 \%$ of normal total activity in plasma and serum, more than $95 \%$ heat denaturable; this migrated like the fast, heat-denaturable band in normal serum and therefore was considered to be hexosaminidase A. Mean activity was slightly lower in plasma than in serum, possibly because of heparin inhibition [27]; in any event, the degree of difference was similar for both patient and control subjects. Leukocyte hexosaminidase activity averaged $10 \%$ of control activity, compared with $<2 \%$ of control in one reported case [39].

In another case of Sandhoff's disease [42], hepatic hexosaminidases levels were almost normal during diphenylhydantoin therapy at toxic doses but were very low after the treatment was stopped, whereas serum enzyme activity remained at $2-5 \%$ of normal $(80-90 \%$ hexosaminidase levels were almost normal during diwas no alteration in plasma or leukocyte hexosaminidase activities in the samples taken after no phenobarbital for 1 week, when serum barbiturate levels had become undetectable. Hexosaminidase activity in the liver biopsy taken at this time, when the possibility of drug effects was minimal, was $<2 \%$ of normal, including $83.5 \%$ heat denaturable, similar to values reported by others.
Fibroblast activity, also, differed from that reported in other cases of Sandhoff's disease. In fibroblasts from our patient, total activity was $7-11 \%$ of mean control value (depending on the method of cell preparation for assay), compared with $5 \%$ in other studies $[3,21$, 23]. Furthermore, Okada et al. [21, 23] reported similar deficiencies in both the $\mathrm{A}$ and $\mathrm{B}$ fractions, whereas, by heat-denaturation criteria, the enzyme in the fibroblasts from our patient was $>95 \%$ hexosaminidase A. It is unlikely that these different heat-denaturation data are attributable to interlaboratory differences in technique, inasmuch as the $\mathrm{A}$ proportion in the control fibroblasts in the study by Okada et al. [23] was similar to that in ours.

The number of hexosaminidases in normal human tissues, and their interrelation, is not clear. In serum, two forms ( $\mathrm{A}$ and $\mathrm{B}$ ) have been observed by Okada and O'Brien [22], three by Lowden and LaRamee [14], and four by Price and Dance [25]; two types have been detected in leukocytes and cultured fibroblasts [11, 23, $38]$, and two $[32,47]$ or possibly three types [12] in liver. Conversion from one form to another by treatment with neuraminidase $[6,18]$ or by heating [25] has been reported.

In our study, cellulose acetate electrophoresis of control specimens demonstrated three bands of activity in serum and leukocytes and two in fibroblasts: in serum, one band was heat denaturable; in leukocytes, one band was denaturable and another partly so; and in fibroblasts, both bands denatured in part. In the serum, leukocyte, and fibroblast preparations of the patient, the chromatographic behavior of the hexosaminidase activity was similar to that of the heat-denaturable component of the control preparations. The different mobilities of the major bands in both control and patient serum compared with leukocytes and fibroblasts may indicate different species of hexosaminidase in these tissues. However, these findings must be interpreted cautiously. The preparations were crude, with widely differing specific activities; therefore, different amounts of protein were spotted for adequate visualization.

The partially purified serum enzyme was identified as hexosaminidase A by column chromatographic separation and electrophoretic mobility. Neither patient nor control enzyme preparations heat denatured entirely, despite electrophoretic migration as a single band with mobility similar to the heat-denaturable band of normal serum, and the minimal heat-stable hexosaminidase activity in the patient's plasma from 
which the purified enzyme was isolated. This may reflect heat-labile to heat-stable conversion of a portion of the partially purified enzyme during manipulation or storage [25]. The $\mathrm{K}_{\mathrm{m}}$ value of the patient's enzyme was slightly higher than control values with both substrates (GalNAc > GIcNAc), which suggested a slight alteration in affinity.

The hexosaminidase activities in serum, plasma, and leukocytes of the mother were intermediate between those of the patient and the normal control subjects. This finding, together with the death of at least three related children with an apparently phenotypically similar illness, indicates the inherited nature of this variant. It is difficult to make a prognosis, but the clinical course of our patient to date, and the history of an apparently similar condition in other members of the kindred, suggest a phenotypic expression similar to that of Sandhoff's and Tay-Sachs disease. The different enzyme activities in his vascular compartment and solid tissues support the recent suggestion [3] that enzyme replacement via plasma or blood transfusion may be of little value in the treatment of hexosaminidase deficiencies.

Most studies of hexosaminidases in $\mathrm{GM}_{2}$ gangliosidoses have used the commercially available artificial substrates; hence, our use of these permits direct comparison. It is appreciated, however, that natural substrates, such as $\mathrm{GM}_{2}$ ganglioside or globoside, may give different findings; normal activity with artificial substrates, but low activity with natural ones has been reported in Tay-Sachs disease var. AB [31]. Should further tissues from this patient become available, we plan to conduct studies with the natural substrates.

It has been suggested that the differences in chromatographic and electrophoretic properties of the major forms of hexosaminidases are due to differences in carbohydrate content $[6,18]$ or indicate that both hexosaminidase $\mathrm{A}$ and $\mathrm{B}$ are multimers with at least one common subunit and a different subunit [3, 37]. The latter theory has received strong support recently from immunochemical [26, 36] and cell hybridization studies [43]. Although the structure of the hexosaminidases in man is not known, the enzyme pattern in our patient shows that some degree of $\mathrm{A}$ activity alone is possible, analogous to $\mathrm{B}$ activity alone in Tay-Sachs disease.

The A activity of the patient's cells, however, was not expressed to the same degree in all tissues; it was highest in plasma and serum (20-24\% of normal), lower in fibroblasts and leukocytes $(7-11 \%$ of normal), and $<2 \%$ of normal in liver. The liver was frozen before analysis; this could have altered enzyme activity, but any such change probably was slight, inasmuch as plasma and serum activity were unaltered by freezing. Furthermore, when freezing/thawing was omitted and albumin was added for protection, mean fibroblast activity increased from $7 \%$ to only $11 \%$. This difference in serum and plasma activity, on the one hand, and liver activity on the other, suggests that the hexosaminidases in serum and plasma differ from those in solid tissues, and that a mutation is possible which can virtually abolish activity in solid tissue but which permits partial activity in serum and plasma. If the latter is derived from the former, by cell turnover and lysosomal enzyme release, our findings suggest that the hexosaminidases may be modified before their entry into the vascular compartment. Such a modification could permit partial restoration of activity to an inactive enzyme. In our case, the phenotypic expression of the disease, and the storage of material in appendiceal neurones, indicate that activity may be very low in brain as well as in liver. The reverse situation, absent hexosaminidase $A$ activity in the serum, with a normal phenotype (and therefore presumably normal activity in brain), has been reported $[19,46]$, and severe deficiency of galactose 1-phosphate uridyltransferase in blood but normal activity in liver has been described in apparently healthy adults [34].

\section{Summary}

A 28-month-old Negro male with clinical, histologic, and chemical findings closely resembling those of Sandhoff's disease is described. Hexosaminidase activity, however, showed important differences: in serum and plasma, total hexosaminidase $(>95 \%$ hexosaminidase A) was 20 to $24 \%$ of normal, compared with $\leqslant 5 \%$ of normal in other reported cases, but in liver, as in other cases, total hexosaminidase was $<2 \%$ of normal.

This case appears to represent a "new" variant of Sandhoff's disease.

\section{References and Notes}

1. Bass, N. H., Wrrmer, E. J., AND Driefuss, F. E.: A pedigree study of metachromatic leukodystrophy: Biochemical identification of the carrier state. Neurology, 20:52 (1970).

2. CReech, B. G., ANd Sewell, B. W.: A rapid micro procedure for determination of free and esterified cholesterol in blood serum using silicic acid separation. Anal. Biochem., 3: 119 (1962).

3. Desnick, R. J., Snyder, P. D., Desnick, S. J., Krivit, W., and 
SHARP, H. L.: Sandhoff's disease: Ultrastructural and biochemical studies. In: S. M. Aronson and B. W. Volk: Sphingolipids, Sphingolipidoses, and Allied Disorders, Ed. 3, p. 351 (Plenum Press, New York, 1972).

4. Embil, J. A., And Faulkner, R. S.: Human diploid cell strains and their susceptibility to viruses. Can. J. Public Health, 55: IIl (1964).

5. Folch, J., Lees, M., and Sloane-Stanlex, G. H.: A simple method for the isolation and purification of total lipides from animal tissues. J. Biol. Chem., 226: 497 (1957).

6. Goldstone, A., Konecny, P., And Koenig, H.: Lysosomal hydrolyases: conversion of acidic to basic forms by neuraminidase. Fed. Eur. Biochem. Soc. Lett., 13: 68 (1971).

7. Gordon, B. A., And Haust, M. D.: The mucopolysaccharidoses types I, II and III: Urinary findings in 23 cases. Clin. Biochem., 3: 203 (1970).

8. Harzer, K., Sandhoff, K., Schall, H., and Kollmann, F.: Enzymatische Untersuchungen in Blut von Ubertragern einer variante der Tay-Sachsschen Erkrankung (Variante O). Klin. Wochenschr., 49: 1189 (1971).

9. Hess, H. H., ANd Lewin, H.: Microassay of biochemical structural components in nervous tissues. II. Methods for cerebrosides, proteolipid proteins and residue proteins. J. Neurochem., 12: 205 (1965).

10. Juif, J. G., Luckel, J. C., Nussbaum, J. L., Stoebner, R., And KAPPS, R.: La gangliosidose GM 2 avec déficit complet en $\beta$ $N$-acétylhexosaminidase ou maladie de Sandhoff. Arch. Fr. Pédiat. 30: 29 (1973).

11. Kanfer, J. N., AND Spielvogel, C.: Hexosaminidase activity of cultured human skin fibroblasts. Biochim. Biophys. Acta, 193: 203 (1973).

12. Kolodny, E. H.: Sandhoff's disease: Studies on the enzyme defect in homozygotes and detection of heterozygotes. In: S. M. Aronson and B. W. Volk: Sphingolipids, Sphingolipidoses, and Allied Disorders. Ed. 3, p. 321 (Plenum Press, New York, 1972).

13. Ledeen, R., Salsman, K., Gonatas, J., and Taghavy, A.: Structure comparisons of the major monosialogangliosides from brains of normal human, gargoylism, and late infantile systemic lipidosis. Part I. J. Neuropathol. Exp. Neurol., 24: 341 (1965).

14. Lowden, J. A., and LaRamee, M. A.: Problems in prenatal diagnosis using sphingolipid hydrolase assays. In: S. M. Aronson and B. W. Volk: Sphingolopids, Sphingolipidoses, and Allied Disorders, Ed. 3, p. 257 (Plenum Press, New York, 1972).

15. Lowry, O. H., Rosebrough, N. J., Farr, R. L., and Randall, R. J.: Protein measurement with the Folin phenol reagent. J. Biol. Chem., 193: 265 (1951).

16. Macmillan, V. H., and Wherrett, J. R.: A modified procedure for the analysis of mixtures of tissue gangliosides. J. Neurochem., 16: 1621 (1969).

17. Miertinen, T., nND Takki-LuUkkarnen, I. T.: Use of butyl acetate in determination of sialic acid. Acta Chem. Scand., 13: $856(1959)$.

18. Murphy, J. V., ANd CratG, L.: Neuraminidase-induced changes in white blood cell hexosaminidase A. Clin. Chim. Acta, 42: 267 (1972).

19. Navon, R., PADEH, B., AND Adam, A.: Apparent deficiency of hexosaminidase $\mathrm{A}$ in healthy members of a family with TaySachs disease. Amer. J. Hum. Genet., 25: 287 (1973).

20. O'Brien, J. S.: Five gangliosidoses. Lanet, ii: 805 (1969).

21. Okada, S., McCrea, M., and O'Brien, J. S.: Sandhoff's disease
$\left(\mathrm{GM}_{2}\right.$ gangliosidosis type 2): clinical, chemical, and enzyme studies in five patients. Pediat. Res., 6: 606 (1972).

22. Okada, S., And O'Brien, J. S.: Tay-Sachs disease: Generalized absence of a beta-D-N-acetylhexosaminidase component. Science, 165: 698 (1969).

23. Okada, S., Veath, M. L., Leroy, J., O’Brien, J. S.: Ganglioside $\mathrm{GM}_{2}$ storage diseases: Hexosaminidase deficiencies in cultured fibroblasts. Amer. J. Hum. Genet., 23: 55 (197I).

24. Parker, F., and Peterson, N. F.: Quantitative analysis of phospholipids and phospholipid fatty acids from silica gel thin-layer chromatograms. J. Lipid Res., 6: 455 (1965).

25. Price, R. G., and Dance, N.: The demonstration of multiple heat stable forms of $N$-acetyl- $\beta$-glucosaminidase in normal human serum. Biochim. Biophys. Acta, 271: 145 (1972).

26. Robinson, D., Carroll, M., and Sxirling, J. L.: Identification of a possible subunit of hexosaminidase $A$ and $B$. Nature, 243: 415 (1973).

27. Robinson, D., And Stirling, J. L.: $N$-acetyl- $\beta$-glucosaminidases in human spleen. I3iochem. J., 107: 321 (1968).

28. Rouser, G., Kritchevsky, G., and Yamamoto, A.: Column chromatographic and associated procedures for separation and determination of phosphatides and glycolipids. In: G. V. Marinetti: Lipid Chromatographic Analysis, Vol. 1, p. 99 (Marcel Dekker, New York, 1967).

29. Sandhoff, K., Andreae, V., and Jatzkewitz, H.: Deficient hexosaminidase activity in an exceptional case of Tay-Sachs disease with additional storage of kidney globoside in visceral organs. Life Sci., 7: 283 (1968).

30. Sandhoff, K., Andreae, U., and Jatzkewitz, H.: Deficient hexosaminidase activity in an exceptional case of Tay-Sachs disease with additional storage of kidney globoside in visceral organs. Pathol. Eur., 3: 278 (1968).

31. Sandhoff, K., Harzer, K., Wassle, W., and Jatzkewitz, H.: Enzyme alterations and lipid storage in three variants of Tay-Sachs disease. J. Neurochem., 18: 2469 (1971).

32. SANDhoff, K., and Wassle, W.: Anreicherung und Charakterisierung zweier Formen der menschlichen $N$-acetyl- $\beta$-Dhexosaminidase. Hoppe-Seyler's Z. Physiol. Chem., 352: 1119 (1971).

33. Schneck, L., Friedland, J., Pourfar, M., Salfer, A., And VolK, B. W.: Hexosaminidase activities in a case of systemic $\mathrm{GM}_{2}$ gangliosidosis of late infantile type. Proc. Soc. Exp. Biol. Med., 133: 997 (1970).

34. SEGAL, S.: Disorders of galactose metabolism. In: J. B. Stanbury, J. B. Wyngaarden and D. S. Fredrickson: The Metabolic Basis of Inherited Disease, Ed. 3, p. 174 (McGraw-Hill, New York, 1972).

35. Sмхтн, I.: Chromatographic and electrophoretic techniques, Vol. 1, p. 246 (Interscience, New York, 1960).

36. SRivastava, S. K., AND Beutler, E.: Antibody against purified human hexosaminidase B cross-reacting with human hexosaminidase A. Biochem. Biophys. Res. Commun., 47: 753 (1972).

37. Srivastava, S. K., and Beutler, E.: Hexosaminidase-A and hexosaminidase-B: Studies in Tay-Sachs and Sandhoff's disease. Nature, 241: 463 (1973).

38. Suzuki, Y., Berman, P. H., And Suzuki, K.: Detection of TaySachs disease heterozygotes by assay of hexosaminidase $A$ in serum and leukocytes. J. Pediat., 78: 643 (1971).

39. Suzukr, Y., Jacob, J. C., Suzukr, K., Kutry, K. M., and Suzukx, $\mathrm{K} .: \mathrm{GM}_{2}$-gangliosidosis with total hexosaminidase deficiency. Neurology, 21: 313 (1971). 
40. Svennerholm, L.: Quantitative estimation of sialic acids. II. A colorimetric resorcinol-hydrochloric acid method. Biochim. Biophys. Acta, 24: 604 (1957).

41. VANCE, D. E., AND SweEley, C. C.: Quantitative determination of the neutral glycosyl ceramides in human blood. J. Lipid Res., 8: 621 (1967).

42. Van Hoof, F., Evrard, P., and Hers, H. G.: An unusual case of $\mathrm{GM}_{2}$-gangliosidosis with deficiency of hexosaminidase $A$ and B. In: S. M. Aronson and B. W. Volk: Sphingolipids, Sphingolipidoses, and Allied Disorders, Ed. 3, p. 343 (Plenum Press, New York, 1972).

43. Van Someren, H., and Van Henegouwen, H. B.: Independent loss of human hexosaminidases $A$ and $B$ in man-chinese hamster somatic cell hybrids. Humangenetik, 18: 171 (1973).

44. VERPOORTE, J. A.: Isolation and characterization of the major $\beta$ - $N$-acetyl-D-glucosaminidase from human plasma. Biochemistry, in press.

45. Vidailhet, M., Neimann, N., Grignon, G., Hartemann, P., Philuppart, M., Paysanx, P., Naber, P., and Floquet, J.: Maladie de Sandhoff (gangliosidose a $\mathrm{GM}_{2}$, de type 2): Étude clinique, biochimique et anatomo-pathologique. Arch. Fr. Pédiat., 30: 45 (1973).

46. VidgofF, J., Buist, N. R. M., ANd O'Brien, J. S.: Absence of $\beta$ - $N$-acetyl-D-hexosaminidase A activity in a healthy woman. Amer. J. Hum. Genet., 25: 372 (1973).
47. Wenger, D. A., Okada, S., and O'Brien, J. S.: Studies on the substrate specificity of hexosaminidase A and B from liver. Arch. Biochem. Biophys., 153: 116 (1972).

48. Wolfe, L. S., Senior, R. G., And Ng Ying Kin, N. M.: Structure of oligosaccharides accumulating in the liver of $\mathrm{GM}_{1}$ gangliosidosis type 1. Fed. Proc., 32: 484 (1973).

49. $\mathrm{GM}_{1}$ and $\mathrm{GM}_{2}$ ganglioside standards were prepared from brain tissues from patients with Tay-Sachs disease and $\mathrm{GM}_{\mathbf{x}}$ gangliosidosis, generously supplied by Dr. J. A. Lowden, Hospital for Sick Children, Toronto, Canada.

50. Dr. J. A. Verpoorte, Department of Biochemistry, Dalhousie University, carried out these isolations. The authors gratefully acknowledge his contributions to this work.

51. Pierce Chemical Company, Rockford, Ill.

52. Sepraphore III, Gelman Instrument Company, Ann Arbor, Mich.

53. This study was supported by grants from the Medical Research Council of Canada (MT-2188), the Department of National Health and Welfare, and the Maritime Provinces of Canada. Dr. M. W. Spence is an Associate of the Medical Research Council of Canada.

54. Requests for reprints should be addressed to: M. W. SPENCE, M.D., Department of Pediatrics, Faculty of Medicine, Dalhousie University, Halifax, Nova Scotia, Canada.

55. Accepted for publication January 23, 1974. 